\title{
The Impact of Dietary Patterns on Health Expenditure in Rural Hainan of China
}

\author{
Wen Yu',2, Shiwei Xu1,2*, Mei Li3 ${ }^{13}$ Zhemin Li1,2, Yu Wang1,2, Ahmed Abdul-Gafar',2 \\ ${ }^{1}$ Agricultural Information Institute, Chinese Academy of Agricultural Sciences, Beijing, China \\ ${ }^{2}$ Key Laboratory of Digital Agricultural Early-Warning Technology, Ministry of Agriculture, Beijing, China \\ ${ }^{3}$ Division of Community Health and Humanities, Faculty of Medicine, Memorial University of Newfoundland, St. \\ John's, NL, Canada \\ Email: yuwen@caas.cn, “xushiwei@caas.cn, meil@mun.ca, lizhemin@caas.cn, 403284815@qq.com, \\ abd.gafar1@icloud.com
}

Received 21 May 2016; accepted 28 May 2016; published 31 May 2016

Copyright (C) 2016 by authors and Scientific Research Publishing Inc.

This work is licensed under the Creative Commons Attribution International License (CC BY).

http://creativecommons.org/licenses/by/4.0/

cC) (7) Open Access

\section{Abstract}

The dietary patterns determine the nutrition structure and suitable nutrition benefits for health. In order to measure the relationship between nutrition and health, this article focuses on the relationship between Dietary patterns and health expenditure. We collected 547 household samples from six counties in rural Hainan Province of China. The authors applied Seemingly Unrelated Regression (SUR) model to estimate the empirical model. The results are: (1) some animal food have significant effect to health expenditure; (2) based on the current analysis, consuming more pork and eggs, health expenditure would significantly increase; while consuming more chicken and fish, health expenditure would significantly decrease. We could conclude that appropriate dietary pattern benefits health; livestock meat consuming, primarily pork, may cause more health care expenditure, while fish-dominant diet could reduce health expenditure.

\section{Keywords}

Dietary Pattern, Health Expenditure, Seemingly Unrelated Regression (SUR), Suggestion

\section{Introduction}

Food and nutrition are the two aspects of the same thing. Food consumption group determines the nutrition structure. The effect of nutrition intake on health is indisputable. The authors exemplify the relationship between diet and diseases in Table 1.

\footnotetext{
${ }^{*}$ Corresponding author.
}

How to cite this paper: Yu, W., Xu, S.W., Li, M., Li, Z.M., Wang, Y. and Abdul-Gafar, A. (2016) The Impact of Dietary Patterns on Health Expenditure in Rural Hainan of China. Open Journal of Social Sciences, 4, 300-304. 
Table 1. The literature summary on the disease associated with diet and nutrition.

\begin{tabular}{|c|c|c|c|c|}
\hline & Author & Data source & Diet and nutrition & Diseases \\
\hline 1 & $\begin{array}{l}\text { Nurmatov U., etc. } \\
\text { (2011) [1] }\end{array}$ & Literature summary & Fruit and vegetable & $\begin{array}{l}\text { Fewer intakes of fruit and vegetable } \\
\text { are related to asthma and allergy for } \\
\text { children }\end{array}$ \\
\hline 2 & $\begin{array}{l}\text { Wang Cannan, } \\
\text { etc. (2001) [2] }\end{array}$ & $\begin{array}{l}\text { Survey on resident's Food consumption } \\
\text { and nutrition-related disease in Xuzhou } \\
\text { City }\end{array}$ & $\begin{array}{l}\text { Energy nutrition intake decreases, } \\
\text { animal protein and fat intake increase }\end{array}$ & $\begin{array}{l}\text { mortality rate of Diabetes, colon } \\
\text { cancer, breast cancer (female), } \\
\text { cerebrovascular disease, } \\
\text { cardiovascular disease increase }\end{array}$ \\
\hline 3 & $\begin{array}{l}\text { Xu Zhanzhong } \\
\text { etc. (2008) [3] }\end{array}$ & $\begin{array}{l}\text { time serial data on food consumption in } \\
\text { Xuzhou City, Jiangsu Province; And } \\
\text { random } 41,786 \text { sample survey on } \\
\text { diseases related nutrition to the } \\
\text { population with age of } 35 \text { years old }\end{array}$ & $\begin{array}{l}\text { Comparing with the idea diet pattern, } \\
\text { milk, beans, aquatics, vegetable, fruit } \\
\text { taken less, and pork, fat and oil taken } \\
\text { more.t intake }\end{array}$ & $\begin{array}{l}\text { Tobacco, alcohol, Obesity will } \\
\text { promote hypertension, stroke, } \\
\text { diabetes, bronchial asthma, chronic } \\
\text { bronchitis, and fruit consumption and } \\
\text { sports activities will protect the health }\end{array}$ \\
\hline 4 & $\begin{array}{l}\text { Wang Cannan, } \\
\text { etc. (2001) [4] }\end{array}$ & $\begin{array}{l}\text { food consumption random sampling } \\
\text { survey and monitoring of disease for } \\
\text { urban and rural residents in Jiangsu } \\
\text { Province }\end{array}$ & $\begin{array}{l}\text { Grains consumption reduced, animal } \\
\text { production increased; Carbohydrate } \\
\text { nutrients intake decreases, fat and } \\
\text { protein intake increases }\end{array}$ & $\begin{array}{l}\text { the resistance of infectious disease } \\
\text { increases; mortality of diabetes, } \\
\text { hypertension, coronary heart disease, } \\
\text { colon cancer, breast cancer (female) } \\
\text { has a rapid growth; }\end{array}$ \\
\hline 5 & $\begin{array}{l}\text { Mo Baoqing, etc. } \\
\text { (2007) [5] }\end{array}$ & $\begin{array}{l}\text { Urban dietary survey on } 240 \\
\text { households in Jiangsu Province }\end{array}$ & $\begin{array}{l}\text { grains intake decreases, while the } \\
\text { intake of beans, meat, poultry, milk, } \\
\text { aquatics, oil and fat increase; in } \\
\text { nutrition, intake of protein, lipids, } \\
\text { riboflavin, retinol equivalent, calcium, } \\
\text { vitamin C increase }\end{array}$ & $\begin{array}{c}\text { Less detection rate of deficiency } \\
\text { disease, and higher detection rate of } \\
\text { over-nutrition related diseases } \\
\text { (children simple obesity, hypertension, } \\
\text { hyperlipidemia, diabetes) }\end{array}$ \\
\hline
\end{tabular}

Fewer intakes of fruit and vegetable are related to asthma and allergy for children, which means that the intake of fruit and vegetable benefits to the patient with asthma and allergy [1];

The unbalanced nutrition, especially more fat intake, are related to some diseases. For example, some chronic disease are associated with dietary fat, such as lard contains saturated fats [6].

The researchers often link the disease with dietary patterns. More pork, fat and oil intake is associated with hypertension, stroke, diabetes, bronchial asthma, chronic bronchitis [3]; while the intake of beans, meat, poultry, milk, aquatics, oil and fat increase, in the role of nutrition, intake of protein, lipids, riboflavin, retinol equivalent, calcium, vitamin $\mathrm{C}$ increase, there is less detection rate of deficiency disease, but higher detection rate of over-nutrition related to diseases, including children obesity, hypertension, hyperlipidemia, diabetes [5]; the similar study also proves that les grains consumption but more animal production, from the degree of nutrition, less carbohydrate intake and more fat and protein intake will lead to the resistance increasing for infectious disease, and also lead to the increasing mortality of diabetes, hypertension, coronary heart disease, colon cancer, breast cancer (female) [4].

Prolonged intake of fat has side effects, such as the chronic disease of cardio-cerebrovascular diseases, thus reduce or interfere fat consumption. So the unhealthy diet structure will possibly cause nutrition imbalance; then thus make persons to deal with the disease and led to increased health expenditure.

In order to measure the relationship between nutrition intake and health, this article focuses on examining the impact of food structure on health care expenditure.

The healthy food structure could be got from empirical analysis, and the authors try to explain the reason from the perspective of nutrition intake. Positive nutrition suggestion is expected to be accepted by relative nutrition management department and governmental sectors. The expected result is that government could take relative measurement to help household establish and maintain a healthy food habitat for further health promotion.

\section{Material and Method}

\subsection{Data}

All data is from face to face questionnaire survey co-implemented by Agricultural Information Institute, Chinese Academy of Agricultural Sciences (AII-CAAS) and Science Information Institute, Chinese Academy of Tropi- 
cal Agricultural Sciences (SII-CATAS) in the end of 2013 in Hainan Province, China (Figure 1),

Hainan province is located at the extreme south of China ranging in $18^{\circ} 10^{\prime}-20^{\circ} 10^{\prime} \mathrm{N}$ and $108^{\circ} 37^{\prime}-111^{\circ} 03^{\prime} \mathrm{E}$. It is an island covering maritime area of about 2 million square kilometres and land area of about 35.4 thousand square kilometres, ranking the province as the $28^{\text {th }}$ compare to other provinces in China.

Six counties were selected among which include Lingao and Danzhou (North-west of the province), Chengmai and Qiongzhong (Central), and Wenchang and Wanning (South-east). Three towns was selected from each county among which three villages were selected and lastly, a total of 547 farmers were randomly select and interviewed; considering the integrity of the food consumption data, 304 effective questionnaires are used in this article.

\subsection{Seemingly Unrelated Regression}

The authors apply Seemingly Unrelated Regression (SUR) to estimate the empirical model [7]. In the model, we make the hypothesis that the most adverse nutritional factor of health is animal products regarding food intake. In Table 2, the authors list the relevant variables in this article. Health expenditure per capita, denoting as pexp_ health, the dependent variable, is RMB803 Yuan averagely in 2013; the social economic variables include housewife education level, household head's age, family size, denoting as edu, age and size, respectively; the food consumption per capita is also list in Table 2, such as staple grains (mainly rice,), red meat (primarily pork), chicken, egg, aquatic productions (fish, shrimp and shells), milk, vegetable, and fruit, denoting as pwei_ grains, pwei_pork, pwei_poul, pwei_egg, pwei_aquatic, pwei_milk, pwei_veg01, pwei_fruit, respectively.

In Table 3, the Logarithm form of variable excluding social economics variables such as edu, age and size, is listed. As is used to estimate the Tobit model and explain the health expenditure in percentage degree, and also validate model results mutually.

The relative characteristic factors are also considered in the analysis, for example housewife education, household head's age, family size, denoting as the logarithm style or proportion: lnedu, lnage, Insize. The logarithm of food consumption also denote as lnpwei_grains, lnpwei_meat, lnpwei_fat, lnpwei_poul, lnpwei_egg, lnpwei_aquatic, lnpwei_milk, lnpwei_veg01, lnpwei_fruit, respectively. And the definition is listed in detail in Table 3.

\section{Results}

From SUR model 1 in Table 2 and Model 2 in Table 3, we can find the primary results as following:

(1) Some animal food consumption has significant effect on health expenditure;

(2) From Table 2, the coefficient of pwei_meat and pwei_egg has positive sign, which means consuming each $1 \mathrm{~kg}$ of pork and eggs, health expenditure would significantly increase RMB15 and 43 Yuan; Contrary to this, the coefficient of pwei_poul and pwei_aquatic has negative sign, which means consuming each $1 \mathrm{~kg}$ of chicken and fish, health expenditure would significantly decrease RMB27 and 10 Yuan.

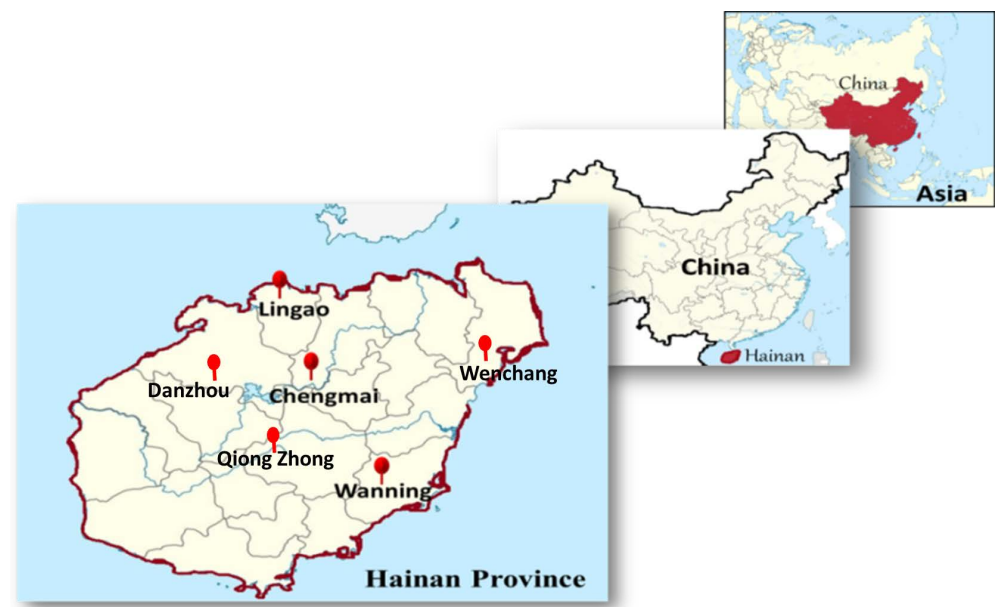

Figure 1. Map-China, Hainan province. 
Table 2. Variable expression and the results from SUR Model 1.

\begin{tabular}{|c|c|c|c|c|c|c|c|}
\hline \multirow[b]{2}{*}{ Variable } & \multirow[b]{2}{*}{ Definition } & \multirow[b]{2}{*}{ Unit } & \multirow[b]{2}{*}{ Mean } & \multicolumn{4}{|c|}{ SUR model } \\
\hline & & & & Coef. & Std.Err. & T-value & $\mathbf{P}>\mathbf{T}$ \\
\hline (1) & (2) & (3) & (4) & (5) & (6) & (7) & (8) \\
\hline pexp_health & Health expenditure per capita & RMB yuan & 803 & - & - & - & - \\
\hline edu & Education level for housewife & Year & 7 & -4.981 & 59.802 & -0.080 & 0.934 \\
\hline age & Age for household head & Year & 47 & 0.430 & 18.970 & 0.020 & 0.982 \\
\hline size & Family size for household & Person & 5 & -78.643 & 123.884 & -0.630 & 0.526 \\
\hline pwei_grains & Grains per capita & $\mathrm{Kg}$ & 309 & -0.334 & 1.072 & -0.310 & 0.756 \\
\hline pwei_meat & Pork per capita & $\mathrm{Kg}$ & 118 & $15.015^{* * *}$ & 5.079 & 2.960 & 0.003 \\
\hline pwei_fat & Fat per capita & $\mathrm{Kg}$ & 17 & -8.981 & 8.935 & -1.010 & 0.316 \\
\hline pwei_poul & Chicken per capita & $\mathrm{Kg}$ & 32 & $-26.914^{* * *}$ & 8.132 & -3.310 & 0.001 \\
\hline pwei_egg & Egg per capita & $\mathrm{Kg}$ & 10 & $42.678^{* * *}$ & 14.233 & 3.000 & 0.003 \\
\hline pwei_aquatic & Fish and other aquatics per capita & $\mathrm{Kg}$ & 51 & $-10.016^{* *}$ & 4.398 & -2.280 & 0.023 \\
\hline pwei_milk & Milk per capita & $\mathrm{Kg}$ & 4 & -18.252 & 20.128 & -0.910 & 0.365 \\
\hline pwei_veg01 & Vegetable per capita & $\mathrm{Kg}$ & 59 & 1.685 & 3.142 & 0.540 & 0.592 \\
\hline pwei_fruit & Fruit per capita & $\mathrm{Kg}$ & 60 & 3.988 & 4.000 & 1.000 & 0.320 \\
\hline _cons & Constant in model & - & - & 215.667 & 1403.919 & 0.150 & 0.878 \\
\hline
\end{tabular}

Note: ${ }^{*} 10 \%$ level significant; ${ }^{* *} 5 \%$ level significant; ${ }^{* * *} 1 \%$ level significant.

Table 3. Variable expression and the results from SUR Model 2.

\begin{tabular}{|c|c|c|c|c|c|c|}
\hline Variable & Definition & Mean & Coef. & Std.Err. & T-value & $\mathrm{P}>\mathrm{T}$ \\
\hline (1) & $(2)$ & (3) & (4) & (5) & (6) & (7) \\
\hline lnpexp_health & Logarithm of health expenditure per capita & 5.34 & - & - & - & - \\
\hline lnedu & Logarithm of education level for housewife & 1.44 & -0.087 & 0.056 & -1.550 & 0.123 \\
\hline lnage & Logarithm of age for household head & 3.81 & 0.231 & 0.239 & 0.970 & 0.335 \\
\hline lnsize & Logarithm of family size for household & 1.61 & 0.189 & 0.260 & 0.730 & 0.467 \\
\hline lnpwei_grains & Logarithm of grains per capita & 5.55 & 0.158 & 0.147 & 1.070 & 0.284 \\
\hline lnpwei_meat & Logarithm of pork per capita & 4.59 & $0.331^{*}$ & 0.182 & 1.810 & 0.071 \\
\hline lnpwei_fat & Logarithm of fat per capita & 1.73 & -0.010 & 0.052 & -0.200 & 0.841 \\
\hline lnpwei_poul & Logarithm of chicken per capita & 2.82 & -0.036 & 0.072 & -0.500 & 0.619 \\
\hline lnpwei_egg & Logarithm of egg per capita & 1.48 & -0.005 & 0.077 & -0.060 & 0.952 \\
\hline lnpwei_aquatic & Logarithm of fish and other aquatics per capita & 3.34 & $-0.152^{* *}$ & 0.076 & -2.010 & 0.045 \\
\hline lnpwei_milk & Logarithm of milk per capita & 0.48 & 0.058 & 0.080 & 0.730 & 0.468 \\
\hline lnpwei_veg01 & Logarithm of vegetable per capita & 3.59 & 0.140 & 0.087 & 1.610 & 0.107 \\
\hline lnpwei_fruit & Logarithm of fruit per capita & 3.65 & $0.223^{*}$ & 0.090 & 2.500 & 0.013 \\
\hline _cons & Constant in model & - & 1.403 & 1.560 & 0.900 & 0.369 \\
\hline
\end{tabular}

Note: ${ }^{*} 10 \%$ level significant; ${ }^{* *} 5 \%$ level significant; ${ }^{* * *} 1 \%$ level significant 
(3) From Table 3, the coefficient of lnpwei_meat and lnpwei_fruit has positive sign, which means consuming each $1 \%$ of pork and fruit more, health expenditure would significantly increase $0.33 \%$ and $0.15 \%$; Contrastly, the coefficient of lnpwei_aquatic has negative sign, which means consuming each $1 \%$ of aquatic productions (mainly fish, also including less shrimp and shells), the health expenditure would decrease $0.15 \%$ significantly.

(4) Anyway, from both SUR model, the variables' sign show interesting results: housewife with higher education has the tendency for health expenditure decreasing, and the household head with older age tends to have health expenditure increasing, although these factors are not significant.

\section{Conclusion and Discussion}

Firstly, healthy dietary pattern benefits health. For example, based on the current research, less pork and more fish, for pork contains saturated fats, which is demonstrated to be associated with obesity and chronic diseases, but fish with highly unsaturated fatty acids has positive effect for physical health.

Secondly, the household characteristics influence the overall family health, housewives with higher education level pay more attention to nutrition intake and health, but household head with older age tends less health care;

Third, families should be encouraged to take the Dietary patterns, and have healthy food for health promotion. Forth, animal fat is an important factor which influences family health, for it contains more saturated fats, sometimes, it is difficult to separate from pork, that is why the pwei_fat in Table $\mathbf{2}$ and lnpwei_fat in Table $\mathbf{3}$ are not significant, for the fat and pork has strongly alternative.

Fifth, in fact, it is better to study the different Dietary patterns in the role of nutrition, for the suitable and balanced nutrition will be helpful with health status.

\section{Acknowledgements}

This article was supported by the CAAS Science and Technology Innovation Project (number: CAAS-ASTIP2016-AII), founded by Chinese Academy of Agricultural Sciences and Technology.

\section{References}

[1] Wooldridge, J.M. (2009) Introductory Econometrics-A Modern Approach (4th), Chapter 17, Limited Dependent Variable Models and Sample Selection Corrections. Tsinghua University Press, Beijing, 540-546.

[2] Weisburger, J.H. (1997) Dietary Fat and Risk of Chronic Disease: Mechanistic Insights from Experimental Studies. Journal of the American Dietetic Association, 97, S16-S23. http://dx.doi.org/10.1016/S0002-8223(97)00725-6

[3] Nurmatov, U., Devereux, G., Sheikh, A. and Liu, G.L. (2011) Nutrients and Foods for the Primary Prevention of Asthma and Allergy. Chinese Journal of Tuberculosis and Respiratory Diseases, 34, 820.

[4] Wang, C.N., Wei, P., Yu, J.X., Kong, Q.L. and Liu, P. (2001) The Effect of Food Consumption Changes On the Morbidity of Certain Nutrition-Related Diseases in Xuzhou Urban Residents during 1990s. Acta Academiae Medicinae Xuzhou, 21, 332-335.

[5] Xu, Z.Z., Lin, J.D., Liu, J. and Xiang, S. (2008) Studies on the Influence of Dietary Structure on Human Certain Diet-related Diseases. China Modern Doctor, No. 19, 128-131.

[6] Wang, C.N., Liang, Z., Wei, P., Ma, F.L., Yu, J.X., Zhang, D.M. and Liu, P.J. (2001) Changes in Dietary Pattern and Certain Nutrition-Related Diseases in Urban and Rural Residents of Jiangsu Province in 1990s. Journal Of Hygiene Research, No. 5, 299-301.

[7] Mo, B.Q., Ma, F.L., Hu, C.Y. and Zhou, M. (2007) Studies on the Relationship between Dietary Nutrition Intake and Disease Change. Food And Nutrition In China, No. 4, 52-54. 